\title{
Exposure to decabromodiphenyl ether (BDE-209) produces mitochondrial dysfunction in rat liver and cell death
}

Lilian C Pereira, Alecsandra O Souza, Maria J Tasso, Alana M C Oliveira, Filipe V Duarte, Carlos M Palmeira \& Daniel J Dorta

To cite this article: Lilian C Pereira, Alecsandra O Souza, Maria J Tasso, Alana M C Oliveira, Filipe V Duarte, Carlos M Palmeira \& Daniel J Dorta (2017) Exposure to decabromodiphenyl ether (BDE-209) produces mitochondrial dysfunction in rat liver and cell death, Journal of Toxicology and Environmental Health, Part A, 80:19-21, 1129-1144, DOI: 10.1080/15287394.2017.1357370

To link to this article: https://doi.org/10.1080/15287394.2017.1357370

Published online: 07 Sep 2017.

Submit your article to this journal $₫$

Џ Article views: 92

View Crossmark data ¿

Citing articles: 8 View citing articles $\square$ 


\title{
Exposure to decabromodiphenyl ether (BDE-209) produces mitochondrial dysfunction in rat liver and cell death
}

\author{
Lilian C Pereira a,b, Alecsandra O Souzac ${ }^{c}$, Maria J Tassoc, Alana M C Oliveirac', Filipe V Duarte ${ }^{\mathrm{d}, \mathrm{e}}$, Carlos M Palmeira ${ }^{\mathrm{d}, \mathrm{e}}$, \\ and Daniel J Dorta ${ }^{\mathrm{C}}$ \\ aSchool of Pharmaceutical Sciences of Ribeirão Preto, Departament of Clinical Analysis, Toxicological and Bromatological, University of São \\ Paulo, Ribeirão Preto, São Paulo, Brazil; bFaculty of Agronomic Sciences of Botucatu, Department of Bioprocesses and Biotechnology, São \\ Paulo State University, Botucatu, São Paulo, Brazil; 'Faculdade de Filosofia, Ciências e Letras de Ribeirão Preto, Departamento de Química, \\ Universidade de São Paulo, Ribeirão Preto, São Paulo, Brazil; ${ }^{\mathrm{d} C N C}$ - Center for Neuroscience and Cell Biology, University of Coimbra, Faculty \\ of Medicine, Coimbra, Portugal; ' Department of Life Sciences, University of Coimbra, Coimbra, Portugal
}

\begin{abstract}
Polybrominated diphenyl ethers (PBDE) are ubiquitous environmental pollutants. Exposure to these chemicals has been associated with developmental neurotoxicity, endocrine dysfunctions, reproductive disorders, and hepatotoxicity. The widespread use of PBDE as flame retardants has culminated in daily exposure of humans and wildlife to these contaminants and resulted in their banned use. Thus assessment of the potential effects of each PBDE congener on living organisms has become cause for concern. The aim of this study was to (1) examine the effects of decabromodiphenyl ether (BDE)-209 on different functions of HepG2 cells and (2) investigate whether this congener is involved in mitochondrial toxicity. The use of multiple methods was employed to (i) study the influence of BDE-209 on mitochondrial permeability transition (MPT) process in mitochondria isolated from rat liver and (ii) determine the consequential cellular damage. Our results showed that BDE-209 induced matrix swelling related to MPT with $10 \mu \mathrm{M}$ and ATP depletion with $0.1 \mu \mathrm{M}$. In addition, $0.5 \mu \mathrm{M}$ BDE-209 reduced HepG2 cell viability, produced collapse of membrane potential, but increased levels of reactive oxygen species (ROS) after $48 \mathrm{~h}$ incubation. After $24 \mathrm{~h}$ with $5 \mu \mathrm{M}$ treatment elevated levels of ROS, DNA fragmentation and cytochrome $c$ release, accompanied by caspase 9 and caspase 3 activation was noted. Taken together, these results suggest that short-duration exposure ( 24 or $48 \mathrm{~h}$ ) to $0.5 \mu \mathrm{M}$ or $5 \mu \mathrm{M}$ BDE-209 concentrations diminished HepG2 cell viability due to apoptosis associated with mitochondrial dysfunction.
\end{abstract}

\section{Introduction}

Polybrominated diphenyl ethers (PBDE) are chemicals widely used as flame retardants in many electronic goods, furniture items, plastics, automobiles, and textiles (McDonald 2002; Stapleton et al. 2009; Stasinska et al. 2013). PBDE are usually more efficient as flame retardants and cheaper than other flame retardants. However, increasing PBDE levels in the environment and human tissue samples in the order of ng/g samples (Eskenazi et al. 2013; Hites 2004; Lee et al. 2013; Meironyte et al. 1999) are a cause for concern. Indeed, these substances produced adverse effects including neurotoxicity, hepatotoxicity, cancer in vivo in the order of $\mu \mathrm{g} / \mathrm{g}$ as well as following a high, single exposure dose of $10 \mathrm{mg} / \mathrm{kg}$
(Alves et al. 2007; Bellinger 2013; Chen et al. 2010; Costa and Giordano 2007; Cowens et al. 2015; Darnerud 2003; Gill et al. 2016; Nash et al. 2013; Zhang et al. 2008b), and in vitro cytotoxicity including the death of hepatic-derived cells in the order of micromoles (Hu et al. 2009; Madia et al. 2004; Souza et al. 2013; Yan et al. 2011).

The PBDE class of compounds comprises 209 different congeners that are mainly available as three mixtures (penta-BDE, octa-BDE, and decaBDE). The decabromodiphenyl ether BDE-209 has been the most marketed compound since the late 1970s (Hale et al. 2006). Some localities of the European Union (EU) have banned production of the deca-BDE mixture since 2008, but a number of

CONTACT Daniel J Dorta $\otimes$ djdorta@ffclrp.usp.br $\Theta$ Faculty of Philosophy, Sciences and Languages of Ribeirão Preto, Department of Chemistry, University of São Paulo, Av. Bandeirantes, 3900, CEP:14040901, Bairro Monte Alegre, Ribeirão Preto, São Paulo, Brazil.

Present address for Daniel J Dorta is Instituto Nacional de Tecnologias Alternativas para Detecção, Avaliação Toxicológica e Remoção de Micropoluentes e Radioativos (INCT-DATREM), Unesp, Instituto de Química, Caixa Postal 355, 14800-900 Araraquara (SP).

Color versions of one or more of the figures in the article can be found online at www.tandfonline.com/uteh.

(c) 2017 Taylor \& Francis 
EU countries (Sacks and Lohmann 2012) and USA still use this mixture because its restriction is only national or regional (Moon et al. 2012).

BDE-209 may impact reproductive functions (Alves et al. 2007) and spontaneous locomotor behavior (Costa and Giordano 2007) in male rats. This congener also disrupts the endocrine system (Riu et al. 2008) by lowering serum levels of thyroxine (T4) in male rats following BDE-209 post-natal exposure (Rice et al. 2007). In addition, BDE-209 interferes with components of normal brain maturation in rodents (Viberg 2009). In vitro studies demonstrated that BDE-209 induced apoptosis in different cell lines mainly via reactive oxygen species (ROS) accumulation (Hu et al. 2007; Jin et al. 2010; Stapleton and Dodder 2008; Zhang et al. 2008a). In addition, less brominated congeners, such as BDE99 BDE-100, and BDE-154, exert toxicity by impairing mitochondrial functions (Pereira et al. 2013; Souza et al. 2013; Yan et al. 2011).

In vitro investigations serve as supportive studies to obtain the activity profile of certain substances or even to identify their main targets and mechanisms underlying toxicity, thereby aiding the design of further in vivo experiments. In fact, to assess the safety of compounds, human cell lines have long been employed in conjunction with mitochondrial function monitoring. It is well-established that substances are primarily absorbed and metabolized in the liver (Jaeschke et al. 2002). Therefore, harmful effects may arise in this organ. Taking this into account, the aim of the present study was to investigate the manner in which BDE-209 affects the function of isolated rat liver mitochondria and examine damage this congener produces in the human hepatoblastoma-derived cell line (HepG2).

\section{Material and methods}

\section{Reagents}

The BDE-209 congener was purchased from AccuStandard (New Haven, USA). Sulforhodamine B (SRB), 3-(4,5-dimethylthiazol-2-yl)-2,5-diphenyltetrazolium bromide (MTT), dimethyl sulfoxide (DMSO), propidium iodide (PI), tert-butyl-hydroperoxide solution (TBHP), Triton X-100, bis-benzimide H 33342 trihydrochloride (Hoechst 33342), rotenone, carbonylcyanide-3-chlorophenylhydrazone (CCCP), succinate, glutamate, malate, adenosine 5'-diphosphate sodium salt (ADP), safranin-O, o- phthalaldehyde (OPT), N-ethylmaleimide (NEM), 1-anilino-8naphthalene sulfonate salt (ANS), 1-[4-(trimethylamino)phenyl]-6-phenylhexa-1,3,5-triene (TMA$\mathrm{DPH})$, 1,6-diphenyl-1,3,5-hexatriene (DPH), ethyleneglycol bis-( $\beta$-aminoethyl ether)-N,N,N',N'-tetraacetic acid (EGTA), 5,5'-dithiobis(2-nitrobenzoic acid) (DTNB), and Ruthenium Red were acquired from Sigma-Aldrich (USA). $2^{\prime}, 7^{\prime}$ Dichlorodihydrofluorescein diacetate $\left(\mathrm{H}_{2} \mathrm{DCFDA}\right)$ and Calcium Green $5 \mathrm{~N}$ were purchased from Molecular Probes (OR, USA). Tetramethylrhodamine methyl ester (TMRM), fetal bovine serum (FBS, GIBCO), 5,6-chloromethyl-2',7'dichlorodihydrofluorescein diacetate, acetyl ester (CM- $\left.\mathrm{H}_{2} \mathrm{DCFDA}\right)$, and "Minimum Essential Medium" (MEM, GIBCO) were purchased from Invitrogen (EUA). Annexin V-FITC was obtained from Proteimax (Brazil). Cisplatin solution was purchased from Cirúgica Mafra (Brazil). All other reagents were of the highest commercially available degree. The amounts of DMSO required to solubilize BDE-209 did not markedly affect the assays $(0.1 \%$ DMSO for all experiments). All stock solutions were prepared with glass-distilled deionized water.

\section{Animals}

Male Wistar rats weighing 180-200 g were used. The Committee for Experimental Animal Care and Use of the University of Sao Paulo, Brazil, approved all the experimental procedures (number 11.1.90.53.3). Animals were kept under a 12-h light:dark cycle, at an ambient temperature of $24 \pm 2^{\circ} \mathrm{C}$, with free access to food and water. After the sacrifice, livers (10-15 g) were immediately removed, sliced, and maintained at $4^{\circ} \mathrm{C}$.

\section{Isolation of mitochondria}

Rat liver mitochondria-enriched fractions were isolated by standard differential centrifugation (Pedersen et al. 1978). Extracted livers (10-15 g) slices were placed into $50 \mathrm{ml}$ medium containing $250 \mathrm{mM}$ sucrose, $1 \mathrm{mM}$ EGTA, and $10 \mathrm{mM}$ HEPES-KOH, $\mathrm{pH}$ 7.2 and homogenized three times for $15 \mathrm{~s}$ at 1-min intervals in a Potter-Elvehjem homogenizer. The homogenates were centrifuged at $580 \times g$ for $5 \mathrm{~min}$, 
and resultant supernatant centrifuged at $10,300 \times g$ for $10 \mathrm{~min}$. The pellets were suspended in $10 \mathrm{ml}$ medium containing $250 \mathrm{mM}$ sucrose, $0.3 \mathrm{mM}$ EGTA, and $10 \mathrm{mM}$ HEPES-KOH, $\mathrm{pH}$ 7.2, which was followed by centrifugation at $3,400 \times g$ for $15 \mathrm{~min}$. The final mitochondrial pellet was suspended in $1 \mathrm{ml}$ medium containing $250 \mathrm{mM}$ sucrose and $10 \mathrm{mM}$ HEPES-KOH, pH 7.2, and used within 3 h. All procedures were conducted at $4^{\circ} \mathrm{C}$, and mitochondrial protein content was determined by the biuret reaction.

\section{Evaluation of interactions with the mitochondrial membrane}

Insertion of DPH, ANS, and TMA-DPH into membranes elicits fluorescence $(F)$ whose static quenching is described by the Stern-Volmer equation: $F^{\circ} / F=1+\mathrm{KSV}$ [Q], where $F^{\circ}$ and $F$ are fluorescence intensities in the absence and presence of the quencher, respectively, and KSV is the Stern-Volmer constant. To evaluate the interactions of BDE-209 with the mitochondrial membrane, mitochondria (1 $\mathrm{mg}$ protein) were incubated with $0.5 \mu \mathrm{M} \mathrm{DPH}$ and $75 \mu \mathrm{M}$ ANS in the standard incubation medium at $30^{\circ} \mathrm{C}$ by $30 \mathrm{~min}$, which was followed by addition of BDE-209 in a final volume of $2 \mathrm{ml}$ and monitored kinetically for $10 \mathrm{~min}$. Fluorescence was measured with F-4500 spectrofluorometer (Hitachi, Tokyo, Japan) at excitation and emission wavelengths of $362 / 432 \mathrm{~nm}, 360 / 430 \mathrm{~nm}$, and $380 / 485 \mathrm{~nm}$ for TMA-DPH, DPH, and ANS, respectively. These probes exhibit affinities for different portions of the mitochondrial membrane, and when interacting with the membrane emit fluorescence. In this way, these probes are employed to monitor the affinity of compounds with the mitochondrial membrane, since a chemical that displays affinity with the mitochondrial membrane displaces the probes with a consequent decrease in emitted fluorescence (Lee et al. 1999).

\section{Continuous-monitoring mitochondrial assays}

Mitochondrial respiration was monitored by polarography on an oxygraph (Hansatech, Norfolk, England) equipped with a Clark-type oxygen electrode. The mitochondria (1 $\mathrm{mg}$ protein) were incubated in $1 \mathrm{ml}$ standard medium containing
$125 \mathrm{mM}$ sucrose, $65 \mathrm{mM} \mathrm{KCl}, 10 \mathrm{mM}$ HEPES$\mathrm{KOH}, 0.5 \mathrm{mM}$ EGTA, and $10 \mathrm{mM} \mathrm{K} \mathrm{HPO}_{4}, \mathrm{pH}$ 7.4 , at $30^{\circ} \mathrm{C}$. The oxidizable substrates for complexes I and II were $5 \mathrm{mM}$ glutamate and malate or $5 \mathrm{mM}$ potassium succinate $(+2.5 \mu \mathrm{M}$ rotenone), respectively.

Mitochondrial swelling was estimated from the decrease in apparent absorbance of $0.4 \mathrm{mg}$ protein at $540 \mathrm{~nm}$. A spectrophotometer Model DU-70 (Beckman, Coulter Inc., Fullerton, CA, USA) was employed to monitor changes in absorbance for 10 min (incubation time with BDE-209). The modulators of mitochondrial swelling $(1 \mu \mathrm{M}$ cyclosporine A (CsA), $0.5 \mu \mathrm{M}$ Ruthenium Red (RR), and $25 \mu \mathrm{M}$ (NEM) were added prior to BDE-209, and the effect was also monitored for $10 \mathrm{~min}$.

\section{Determination of ATP}

Mitochondrial ATP was determined by means of the firefly luciferin-luciferase assay system. The mitochondrial suspension ( $1 \mathrm{mg}$ of protein in $1 \mathrm{ml}$ ) was centrifuged at $9,000 \times \mathrm{g}$ and $4^{\circ} \mathrm{C}$ for $5 \mathrm{~min}$, and the pellet treated with $1 \mathrm{ml}$ ice-cold $1 \mathrm{M} \mathrm{HClO}_{4}$. After centrifugation at $14,000 \times \mathrm{g}$ and $4^{\circ} \mathrm{C}$ for $5 \mathrm{~min}$, aliquots $(100 \mu \mathrm{l})$ of supernatants were neutralized with $70 \mu \mathrm{l} 2 \mathrm{M} \mathrm{KOH}$ suspended in $100 \mathrm{mM}$ Tris$\mathrm{HCl}, \mathrm{pH} 7.8$ ( $1 \mathrm{ml}$ final volume), and centrifuged again. The bioluminescence was measured in the supernatant by using a Sigma-Aldrich assay kit (according to the manufacturer's instructions) and an AutoLumat LB953 Luminescence photometer (Perkin Elmer Life Sciences, Wildbad, Germany).

\section{Cell culture}

HepG2 cells (American Type Culture Collection number HB8065) were cultured in MEM supplemented with $10 \%$ FBS in atmosphere containing $5 \% \mathrm{CO}_{2}$, at $37^{\circ} \mathrm{C}$. Cells were allowed to reach a confluence $(85 \%)$ that was suitable to start the tests. After this procedure, adequate amounts of the cells were plated for $24 \mathrm{~h}$ to ensure reliable adhesion before the experiments.

\section{Cell proliferation and viability assays}

To evaluate the effect of BDE-209 on cell proliferation and viability, the influence of BDE-209 
concentrations ranging from 0.1 to $25 \mu \mathrm{M}$ was determined using the SRB colorimetric assay described by Skehan et al. (1990). Briefly, HepG2 cells were cultured at a density of $5 \times 10^{4}$ cells per well and exposed to BDE-209 for 24 or $48 \mathrm{~h}$. The medium was discarded, and cells washed once with phosphate buffer saline (PBS) and twice with distilled water to remove salts, dried at room temperature, and subsequently fixed with $1 \%$ methanol in acetic acid solution (1\%) for $2 \mathrm{~h}$. Fixed cells were stained with $0.5 \%$ SRB solution in $1 \%$ acetic acid and washed with $1 \%$ acetic acid solution to remove excess probe. The SRB that attached to the cell membrane was extracted with $1 \mathrm{ml} 10 \mathrm{mM}$ Tris solution, $\mathrm{pH} 10$.

Cell viability was assessed by the MTT assay according to Denizot and Lang (1986). HepG2 cells were cultured at a density of $5 \times 10^{4}$ cells per well as the same condition described above. Subsequently, cells were incubated with $0.5 \%$ MTT $(5 \mathrm{mg} / \mathrm{ml})$ solution in atmosphere containing $5 \%$ $\mathrm{CO}_{2}$ at $37^{\circ} \mathrm{C}$ for $3 \mathrm{~h}$. After this period, the medium from the wells was discarded, and resulting formazan crystals solubilized with DMSO and $0.2 \mathrm{M}$ glycine buffer solution, $\mathrm{pH}$ 10.2. The final absorbance was measured in a microplate reader (Varian Cary 50 MPR, Varian, USA) at 540 and $570 \mathrm{~nm}$ for proliferation and viability, respectively. Data are provided as \% values in treated cells in comparison with non-treated (control) cells taking control as $100 \%$

\section{Mitochondrial membrane potential and accumulation of reactive oxygen species}

Mitochondrial depolarization was examined on the basis of cell retention of the fluorescent dye TMRM as described by Imberti et al. (1993). Cells ( 1 x $10^{5}$ cells per well) were incubated in the absence (control) or presence of BDE-209 at final concentrations ranging from 0.1 to $25 \mu \mathrm{M}$. The cell suspensions were washed with PBS, trypsinized, and incubated with $6.6 \mu \mathrm{M}$ TMRM solution at $37^{\circ} \mathrm{C}$ for $30 \mathrm{~min}$. Subsequently, samples were lysed with $0.1 \%$ Triton $\mathrm{X}-100$ solution $(\mathrm{v} / \mathrm{v})$, and TMRM that was captured and retained by mitochondria was measured at 485 and $590 \mathrm{~nm}$ of excitation and emission, respectively, with an F-4500 Fluorescence Spectrophotometer (Hitachi, Tokyo, Japan). The results are expressed as \% fluorescence in relation to control taking control as $100 \%$.

In addition, intracellular $\mathrm{H}_{2}$ DCFDA oxidation to 2,7-dichlorofluorescein (DCF) by ROS was assessed as indicator of intracellular ROS accumulation (Chernyak et al. 2006). Cells ( $1 \times 10^{5}$ cells per well) were incubated under the same conditions described above. Then cells were incubated with $2 \mathrm{mM}$ $\mathrm{CM}-\mathrm{H}_{2} \mathrm{DCF}-\mathrm{DA}$ solution at $37^{\circ} \mathrm{C}$ for $1 \mathrm{~h}$. Subsequently, $\mathrm{CM}-\mathrm{H}_{2} \mathrm{DCFDA}$ fluorescence was measured with an F-4500 Fluorescence Spectrophotometer (Hitachi, Tokyo, Japan) at 503 and $528 \mathrm{~nm}$ of excitation and emission, respectively. Data are presented as difference from control. TBHP solution $(100 \mu \mathrm{M})$ was used to induce oxidative stress.

\section{Phosphatidylserine exposure on the outer cell membrane (Annexin $v$ assay) and nuclear fragmentation}

Phosphatidylserine exposure was evaluated by using Annexin-V combined with a fluorescent agent for identification of an apoptotic process (Zhivotovsky et al. 1999). HepG2 cells $\left(1 \times 10^{5}\right)$ were cultured and treated in the absence (control) and presence of BDE-209 $(1-25 \mu \mathrm{M})$. Then, cells were incubated with $0.25 \mu \mathrm{g} / \mathrm{ml}$ FITC-Annexin-V solution for $15 \mathrm{~min}$, and $0.5 \mu \mathrm{g} / \mathrm{ml}$ PI solution was added immediately before the analysis. Cells were analyzed with a BD-FACSCANTO ${ }^{\mathrm{TM}}$ flow cytometer (BD Bioscience, CA, USA) and BD-FACSDIVA software (BD Bioscience, CA, USA).

Nuclear fragmentation was also investigated by using the fluorescent dye Hoechst 33342. Briefly, HepG2 cells were seeded at a density of $1 \times 10^{4}$ cells on coverslips and treated with BDE-209 at final concentrations ranging from 0.1 to $25 \mu \mathrm{M}$ for 24 or $48 \mathrm{~h}$. Each sample was assayed in at least three replicates. The cells on the coverslips were fixed with methanol at $-20^{\circ} \mathrm{C}$ for $2 \mathrm{~h}$, which was followed by staining with $5 \mu \mathrm{g} / \mathrm{ml}$ Hoechst 33342 at $37^{\circ} \mathrm{C}$ for $30 \mathrm{~min}$. Nuclear fragments were observed by fluorescence microscopy using a Leica DM 5000B microscope (Germany); 300 cells were quantified in each slide. 


\section{Mitochondrial cytochrome c release}

To investigate the factors involved in the intracellular toxicity of BDE-209 to HepG2 cells, cytochrome $c$ (cyt $c$ ) was quantified in the mitochondrial fractions. After exposure to BDE-209 for 24 or $48 \mathrm{~h}$, cells were incubated with digitonin solution at $50 \mu \mathrm{g} / 10^{6}$ cells per well for $2 \mathrm{~min}$, followed by centrifugation at $1000 \mathrm{~g}$ for $3 \mathrm{~min}$. After collection of the supernatant, the pellet was incubated with RIPA buffer for $30 \mathrm{~min}$ and centrifuged at $14,000 \mathrm{~g}$ for $20 \mathrm{~min}$, to obtain the mitochondrial protein fractions.

The proteins were quantified by electrophoresis in sodium dodecyl sulfate/polyacrylamide gel (SDS-PAGE) as described by Laemmli (1970). Voltage of 90 and $120 \mathrm{mV}$ was utilized to assess protein passage through the stacking gel and protein migration through the resolution gel, respectively. This was followed by transfer of the proteins to nitrocellulose polyvinylidene fluoride (PVDF) (BioRad) membrane with transfer buffer containing $25 \mathrm{mM}$ Trizma, $10.2 \mathrm{mM}$ glycine, and $10 \%$ methanol for $90 \mathrm{~min}$, at a constant voltage of 120 $\mathrm{mV}$. The PVDF membrane was blocked with a solution consisting of $5 \%$ milk (BioRad) in Triz/ Tween 20 (0.1\%) buffer for $90 \mathrm{~min}$.

The membrane was incubated overnight with primary antibodies specific for each analysis: cytochrome $c(15 \mathrm{kDa})$ and anti-VDAC $1(31 \mathrm{kDa})$. The antibodies were prepared in washing solution containing 0.5 M Trizma, $1.5 \mathrm{M} \mathrm{NaCl}, 0.5 \%$ Tween 20 , and $1 \%$ blocking buffer Western Dot (Invitrogen). The membranes were washed, incubated with secondary antibody at room temperature for $60 \mathrm{~min}$, and then incubated with fluorescent solution containing Qdot nanocrystals TM (Invitrogen) for $60 \mathrm{~min}$. The fluorescence of the membrane protein bands was revealed with a Gel Doc EZ-Imager ${ }^{\mathrm{TM}}$ and quantified by densitometry analysis of the bands with the aid of the Image J software.

\section{Caspase 3 and caspase 9 activation}

To determine the factors involved in intracellular toxicity of BDE-209 on HepG2 cells, caspase 3 and caspase 9 were quantified by using total protein fractions, after exposure to BDE-209 for 24 or $48 \mathrm{~h}$. The same procedure described above for western blot was conducted in the case of membrane overnight incubation with primary antibodies specific for each analysis, namely procaspase $3(32 \mathrm{kDa})$, pro-caspase $9(45 \mathrm{kDa})$, and actin $1(31 \mathrm{kDa})$. The antibodies were prepared in washing solution containing $0.5 \mathrm{M}$ Trizma, $1.5 \mathrm{M}$ $\mathrm{NaCl}, 0.5 \%$ Tween 20 , and $1 \%$ blocking buffer Western Dot (Invitrogen). The membranes were washed, exposed to Amersham ${ }^{\mathrm{TM}}-\mathrm{ECL}^{\mathrm{TM}}$ Prime Western Blotting Detection Reagent (GE Health Care), and quantified by densitometry analysis of the bands with the aid of the Image J software.

\section{Statistical analysis}

Data were subjected to analysis of variance (ANOVA) followed by Dunnett's test to compare the several treated groups to their control by means of the program GraphPrism, version 5.1 for Windows. Results with $p<0.05$ were considered statistically significant.

\section{Results}

\section{Effects of BDE-209 on isolated mitochondria}

After 30 min exposure of mitochondria to BDE-209, monitoring of ANS fluorescence revealed that BDE-209 permeated the hydrophilic portion of the inner mitochondrial membrane (Figure 1A). However, this insertion did not markedly affect mitochondrial oxidative phosphorylation capacity. Figure $1 \mathrm{~B}$ shows the state 3 respiration rate (V3) as a function of the BDE-209 concentration after induction of state 3 respiration with $5 \mathrm{mM}$ glutamate plus malate and $5 \mathrm{mM}$ succinate plus rotenone. Further, BDE-209 did not significantly inhibit the respiratory chain components or ATP synthase. The state 4 respiration rate (V4) was not markedly changed (data not shown).

To examine whether BDE-209 influenced mitochondrial functions, induction of mitochondrial pore permeability was determined by observing mitochondrial swelling at $540 \mathrm{~nm}$. The absorbance of mitochondrial suspension was significantly decreased at all tested BDE-209 concentrations, but this fall was more pronounced at BDE-209 concentrations of $10 \mu \mathrm{M}$ and higher (Figure 2A). Addition of $1 \mu \mathrm{M}$ CsA, a classic inhibitor of mitochondrial swelling, significantly blocked this effect 

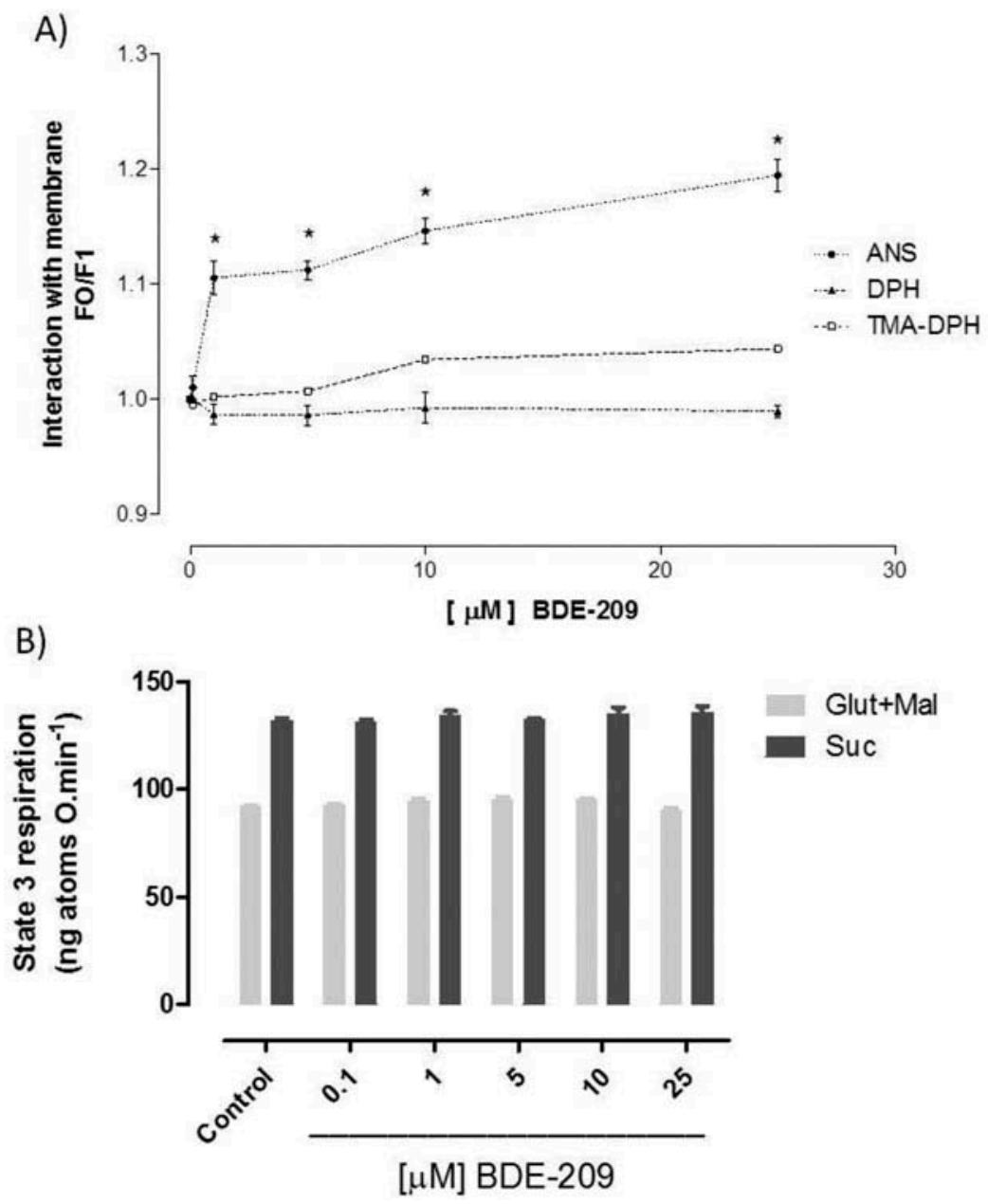

Figure 1. (A) Interaction of BDE-209 (0.1-50 $\mu \mathrm{M})$ with the mitochondrial membrane as monitored with 1,6-diphenyl-1,3,5-hexatriene (DPH) to assess the hydrophobic portion of the membrane and with and 1-anilino-8-naphthalene sulfonate (ANS) and 1-[4-(trimethylamino)phenyl]-6-phenylhexa-1,3,5-triene (TMA-DPH) to assess the hydrophilic portion of the membrane. The mitochondria were incubated in standard reaction medium containing $125 \mathrm{mM}$ sucrose, $65 \mathrm{mM} \mathrm{KCl}, 10 \mathrm{mM} \mathrm{HEPES}-\mathrm{KOH}, \mathrm{pH} 7.2(+2.5 \mu \mathrm{M}$ rotenone, $5 \mathrm{mM}$ potassium succinate, and $1 \mathrm{mM} \mathrm{CCCP).} \mathrm{The} \mathrm{relative} \mathrm{fluorescence} \mathrm{units} \mathrm{(R.F.U.)} \mathrm{were} \mathrm{measured} \mathrm{before} \mathrm{and} \mathrm{after}$ addition of BDE-209 and are presented as the $F^{\circ} / F$ ratio, where $F^{\circ}$ and $F$ are the fluorescence intensities in the absence and presence of BDE-209. (B) The effects of BDE-209 $(0.1-50 \mu \mathrm{M})$ on state 3 of the isolated rat liver mitochondrial respiration energized by glutamate plus malate $(5 \mathrm{mM})$ and succinate $(5 \mathrm{mM})$. The mitochondria were incubated in standard reaction medium containing $125 \mathrm{mM}$ sucrose, $65 \mathrm{mM} \mathrm{KCl}, 10 \mathrm{mM}$ HEPES-KOH, $0.5 \mathrm{mM} \mathrm{EGTA}$, and $10 \mathrm{mM} \mathrm{K} \mathrm{HPO}_{4}$, pH 7.2. State 3 was initiated by using $400 \mathrm{nmol}$ of ADP. Data presented as the means \pm SEM of a series of three experiments. ${ }^{*}$ Significantly different $(p<0.05)$ from control (without BDE-209).

(Figure 2B). Because different cytotoxic agents affect ATP production and/or consumption, mitochondrial ATP content was measured. BDE-209 significantly lowered mitochondrial ATP levels (Figure 3). Based on our previous results showing that BDE-209 altered mitochondrial function in isolated mitochondria, it was of interest to determine whether the same effect might occur in a more complex model and whether BDE-209-induced mitochondrial dysfunction resulted in lethality.

\section{Effects on HEPG2 cells}

Incubation of HepG2 cells with BDE-209 interfered with cell growth only at $25 \mu \mathrm{M}$ after $48 \mathrm{~h}$ exposure. BDE-209 reduced cell viability as assessed by the MTT assay at 24 and 48 h treatment (Figure $4 \mathrm{~A}$ and 4B). The mitochondrial membrane potential was only decreased at the highest tested BDE-209 concentration $(25 \mu \mathrm{M})$, after $48 \mathrm{~h}$ (Figure 5) as evidenced by cell growth disruption. 


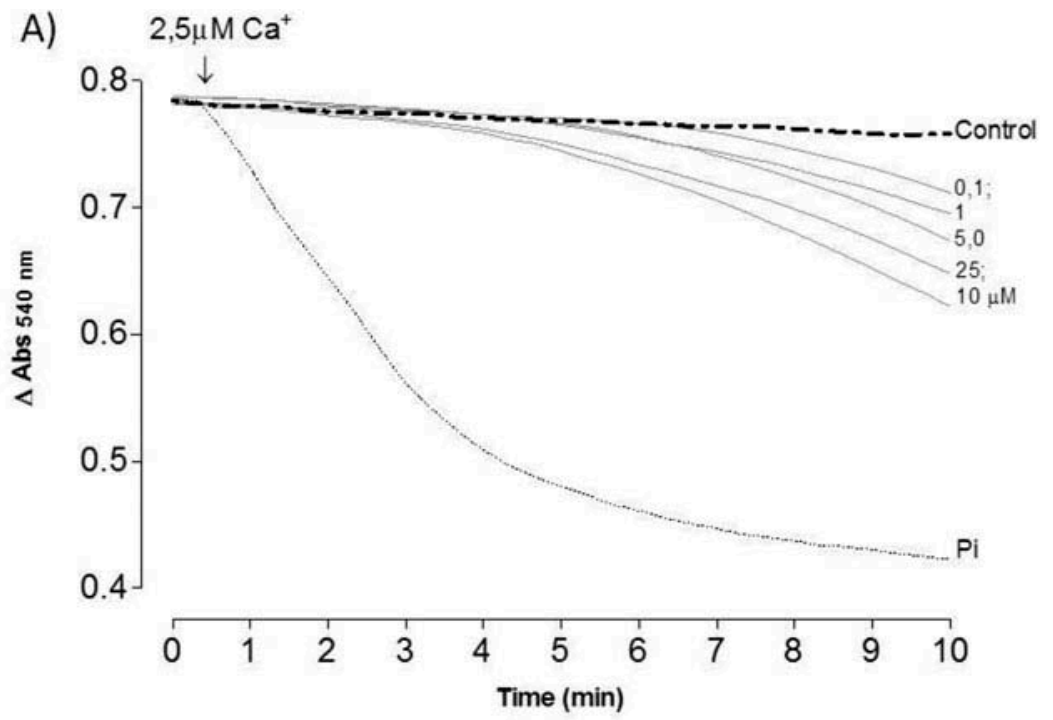

B)

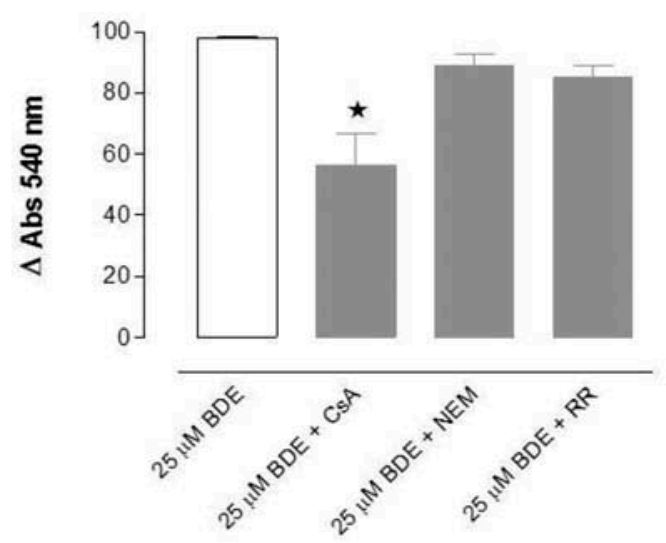

Figure 2. The effects of BDE-209 $(0.1-50 \mu \mathrm{M})$ on mitochondrial swelling (A), and the effects of the modulators Cyclosporin $A(C s A)$, $\mathrm{N}$-ethylmaleimide (NEM), and Ruthenium Red (RR) on the effect of $50 \mu \mathrm{M}$ BDE-209 (B). The mitochondria were incubated in standard reaction medium ( $125 \mathrm{mM}$ sucrose, $65 \mathrm{mM} \mathrm{KCl}, 10 \mathrm{mM}$ HEPES- $\mathrm{KOH}, \mathrm{pH} 7.2$ ) plus $10 \mathrm{mM} \mathrm{Ca}{ }^{2+}$.Data presented as the means \pm SEM of a series of three experiments. ${ }^{*}$ Significantly different $(p<0.05)$ from control (without BDE-209). $\mathrm{Pi}(1 \mathrm{mM})$ was used as the positive control.

In contrast, ROS accumulation increased after incubation of HepG2 cells with $5 \mu \mathrm{M}$ BDE-209 for $24 \mathrm{~h}$. This effect was even more pronounced after $48 \mathrm{~h}$, and at $48 \mathrm{~h}$, results were significant even for incubation of cells with $1 \mu \mathrm{M}$ BDE-209 (Figure 6). Hence, BDE-209 at lower concentrations affected homeostasis of HepG2 cells after $24 \mathrm{~h}$, and higher BDE-209 levels produced mitochondrial impairment and consequent cell death.

It was of interest to examine whether evidence of cytotoxicity was accompanied by exposure to phosphatidylserine (PS) on the outer HepG2 cell membrane. BDE-209 induced annexin-V-positive cells after 24 or $48 \mathrm{~h}$ incubation. In the presence of PS cytotoxicity was significantly elevated for $25 \mu \mathrm{M}$ BDE-209 after $24 \mathrm{~h}$ (Figure 7A and 7B) and for $10 \mu \mathrm{M}$ BDE-209 after $48 \mathrm{~h}$. Further, $10 \mu \mathrm{M}$ and $25 \mu \mathrm{M}$ BDE-209 increased the amount of cells with fragmented nuclei after 48 and $24 \mathrm{~h}$ incubation, respectively (Figure 8). Data were presented in \% in relation to control to facilitate comprehension. The positive control cisplatin showed on average 45 and 70 cells with fragmented nuclei at 24 and $48 \mathrm{~h}$, respectively.

At $25 \mu \mathrm{M}, \mathrm{BDE}-209$ promoted cyt $c$ release after 24 and $48 \mathrm{~h}$ treatment, which may result in apoptotic cell death at this concentration (Figure 9). Decreased pro-caspase 3 and pro-caspase 9 levels also attested to activation of the mitochondrial pathway of apoptotic cell death. Figure 10 illustrates that incubation of HepG2 cells with $5 \mu \mathrm{M}$ or $1 \mu \mathrm{M}$ BDE-209 for 24 and 


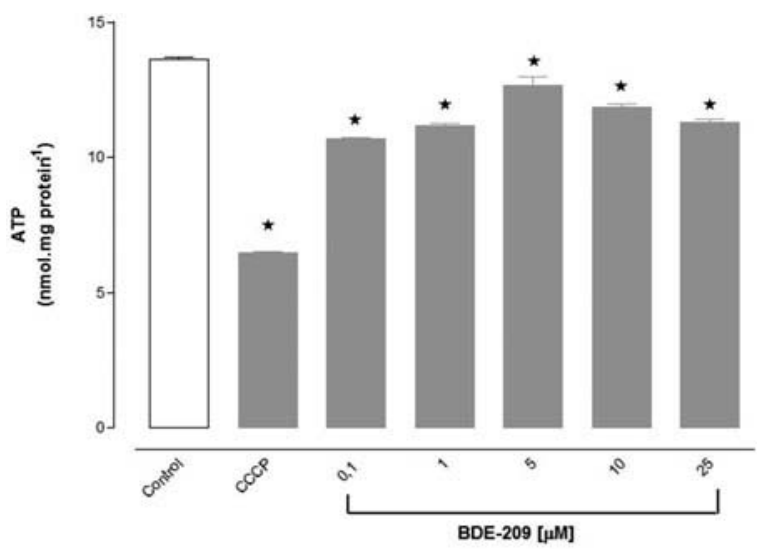

Figure 3. The influence of BDE-209 $(0.1-50 \mu \mathrm{M})$ on ATP content. Mitochondria were incubated in standard reaction medium (125 mM sucrose, $65 \mathrm{mM} \mathrm{KCl}, 10 \mathrm{mM}$ HEPES-KOH, $\mathrm{pH}$ 7.2) and assessed as described in Materials and Methods. Data presented as the means \pm SEM of a series of three experiments with different mitochondrial preparations. *Significantly different $(p<0.05)$ from control (without BDE-209). CCCP (1 mM) was used as the positive control.
$48 \mathrm{~h}$, respectively, activated caspase 3 . The levels of pro-caspase 9 (Figure 11), a mitochondrial activated caspase, were also diminished under the same conditions described above for caspase 3 .

\section{Discussion}

Over the past years, the toxicity of several PBDE congeners has been reported, which is worrisome even though the use of some of these congeners has been banned from places including Europe. However, BDE congeners are still widely used as flame retardant in many household materials in countries where no apparent legislation exists (Pereira et al. 2015). There have been a growing number of investigations regarding the neurotoxic potential of these congeners (Chen et al. 2010; Costa and Giordano 2007, 2011; Goodman 2009; Gill et al. 2016); these compounds are also known

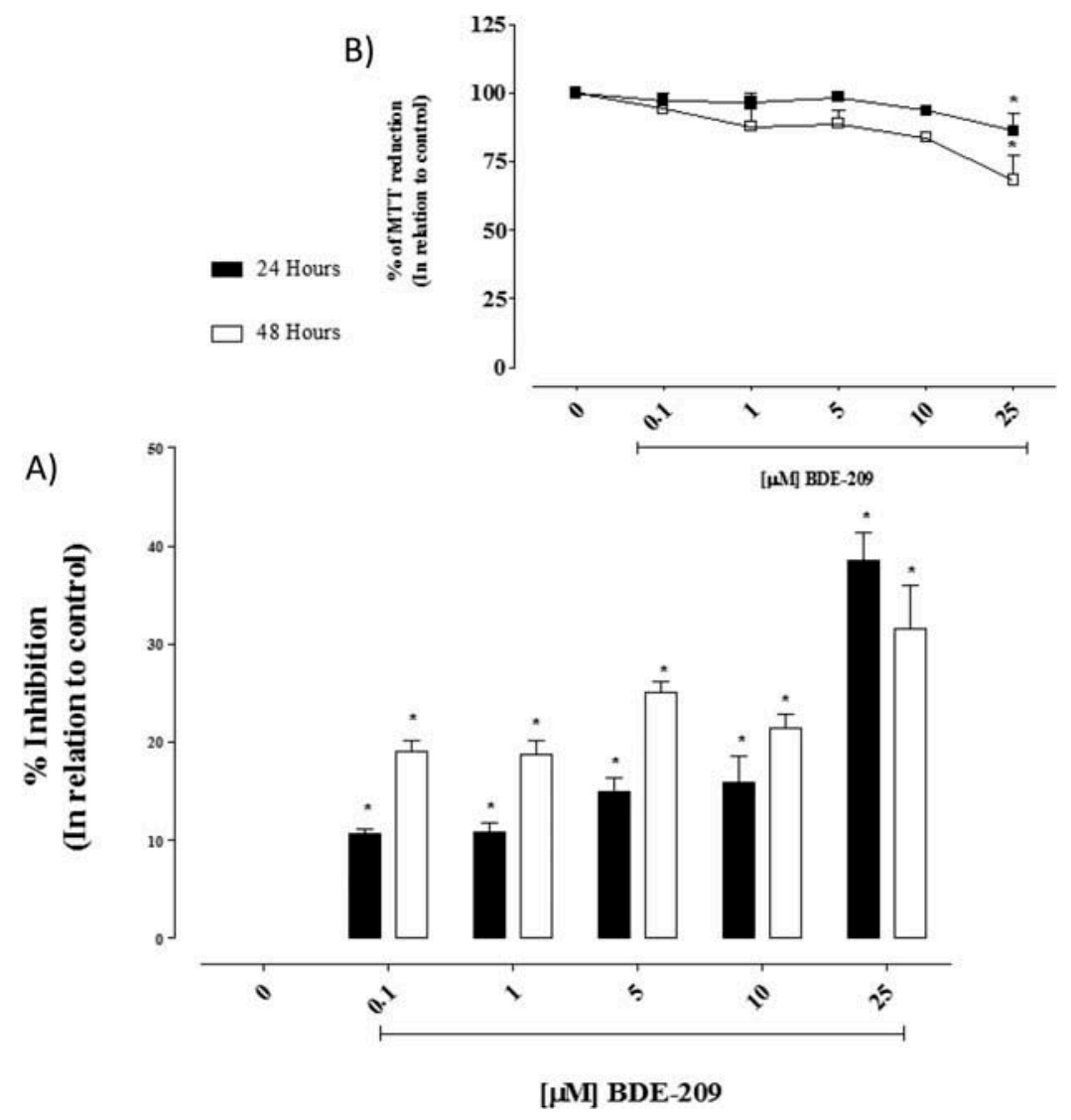

Figure 4. (A) BDE-209 (0.1-25 $\mu \mathrm{M})$ effects on HepG2 cell proliferation after 24 or $48 \mathrm{~h}$ incubation HepG2 cells. Cell proliferation was assessed by using sulforhodamine B (SRB), as described in Materials and Methods. (B) BDE-209 (0.1-25 $\mu$ M) effects on the HepG2 MTT reduction after 24 and $48 \mathrm{~h}$ incubation of HepG2 cells. Cell viability was assessed by the MTT assay, as described in Materials and Methods. Data presented as the means \pm SEM of a series of three experiments. *Significantly different $(p<0.05)$ from negative control (without BDE-209). 


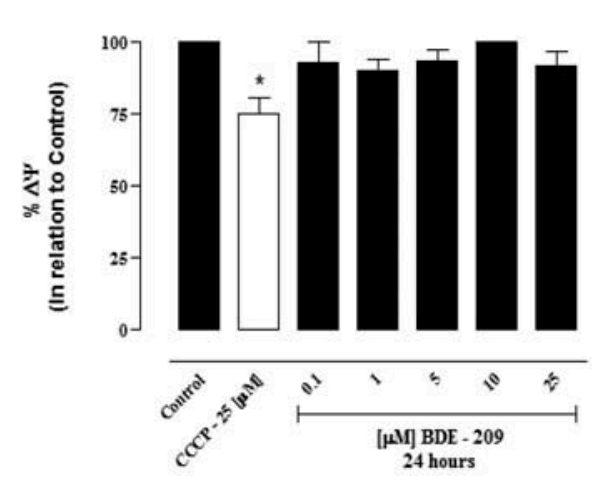

B

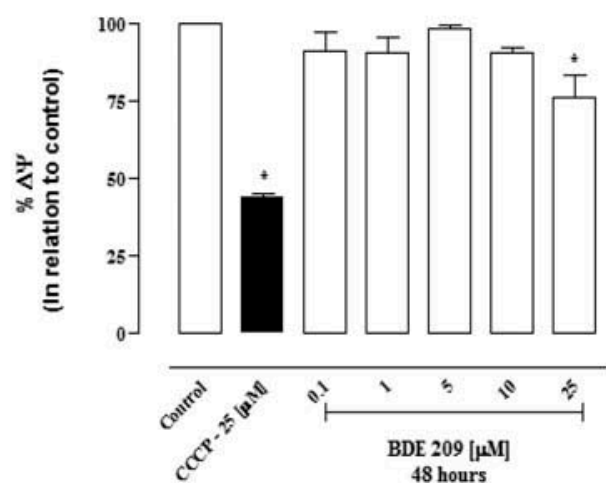

Figure 5. BDE-209 (0.1-25 $\mu \mathrm{M})$ effects on mitochondrial membrane potential (MMP) of HepG2 cells after 24 or $48 \mathrm{~h}$ incubation of cells. The MMP was assessed by using TMRM (tetramethyrodamine, methyl ester) as described in Materials and Methods. Data presented as means \pm SEM of a series of three experiments. ${ }^{*}$ Significantly different $(p<0.05)$ from negative control (without BDE-209). CCCP $(25 \mu \mathrm{M})$ was used as positive control.

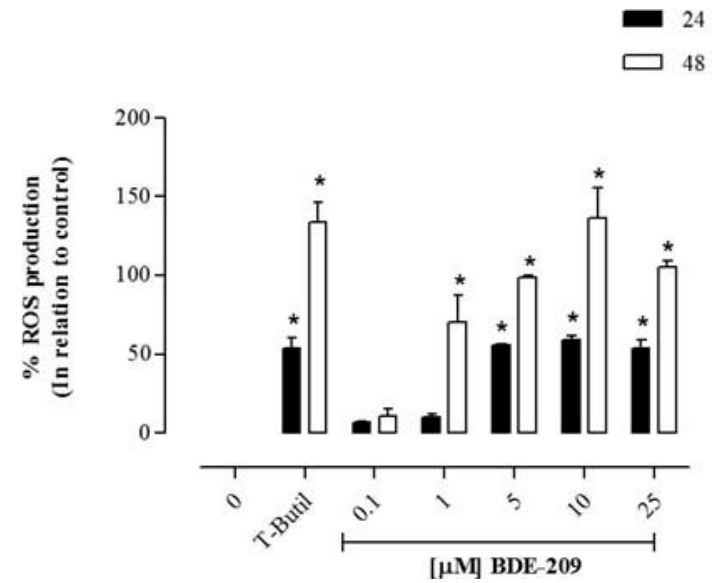

Figure 6. BDE-209 (0.1-25 $\mu \mathrm{M})$ effects on induction of ROS in HepG2 cells after 24 or $48 \mathrm{~h}$ incubation. ROS accumulation was assessed with the fluorescence probe 5,6-chloromethyl-2',7'-dichlorodihidrofluorescein diacetate, acetyl ester (CM- $\left.\mathrm{H}_{2} \mathrm{DCFDA}\right)$ as described in Materials and Methods. Data presented as the means \pm SEM of a series of three experiments. *Significantly different $(p<0.05)$ from negative control (without BDE-209). The positive control was $100 \mu \mathrm{M}$ tert-butyl hydroperoxide (TBHP).

to produce liver damage (Cowens et al. 2015; Nash et al. 2013; Souza et al. 2013; Zhang et al. 2008a). Recently, PBDE were found to produce mitochondrial damage, which interfered in cell homeostasis (Hu et al. 2007, 2009; Pazin et al. 2015; Pereira et al. 2013, 2014; Souza et al. 2013).

As previously observed with BDE-100 (Pereira et al. 2013), BDE-209 interacts with the mitochondrial membrane at all tested concentrations and significant effects started at $1 \mu \mathrm{M}$. BDE-209 predominantly interacts with the hydrophilic portion of the membrane (as monitored by ANS and
TMA-DPH), as expected from the high octanol/ water coefficient $\left(\log K_{\mathrm{ow}}>6\right)$ of BDE-209 (Dietz et al. 2007). Unlike BDE-100 (Pereira et al. 2013), interaction of BDE-209 with the mitochondrial membrane did not markedly modify oxygen consumption by the electron transport chain of the organelle in of glutamate+malate and succinateinduced $\mathrm{O}_{2}$ consumption. In addition, BDE-209 did not significantly dissipate the mitochondrial membrane potential (MMP). Data suggest that the mitochondrial bioenergetics parameters remain unchanged after exposure of mitochondria to BDE-209 in vitro.

Varying results for the effects of PBDE congeners on isolated mitochondria are usual as these congeners display distinct three-dimensional conformation (Figure 12), which may culminate in different capacities to interfere in mitochondrial functions. Indeed, studies on other classes of compounds showed that different structures exert varying effects on isolated mitochondria. Examples of these other compounds are nimesulide and its metabolite (Mingatto et al. 2000), contaminants such as polychlorinated biphenyls (PCB) (Shen et al. 2011), and three pairs of hexabromocyclododecane (Zhang et al. 2008a).

Interaction of compounds with the mitochondrial membrane opens the permeability transition pore. Although the structure of the MPT pore, a protein channel, is still a matter of debate, CsA (used as modulator herein) is a well-established MPT inhibitor. Indeed, CsA prevents MPT 
(a)
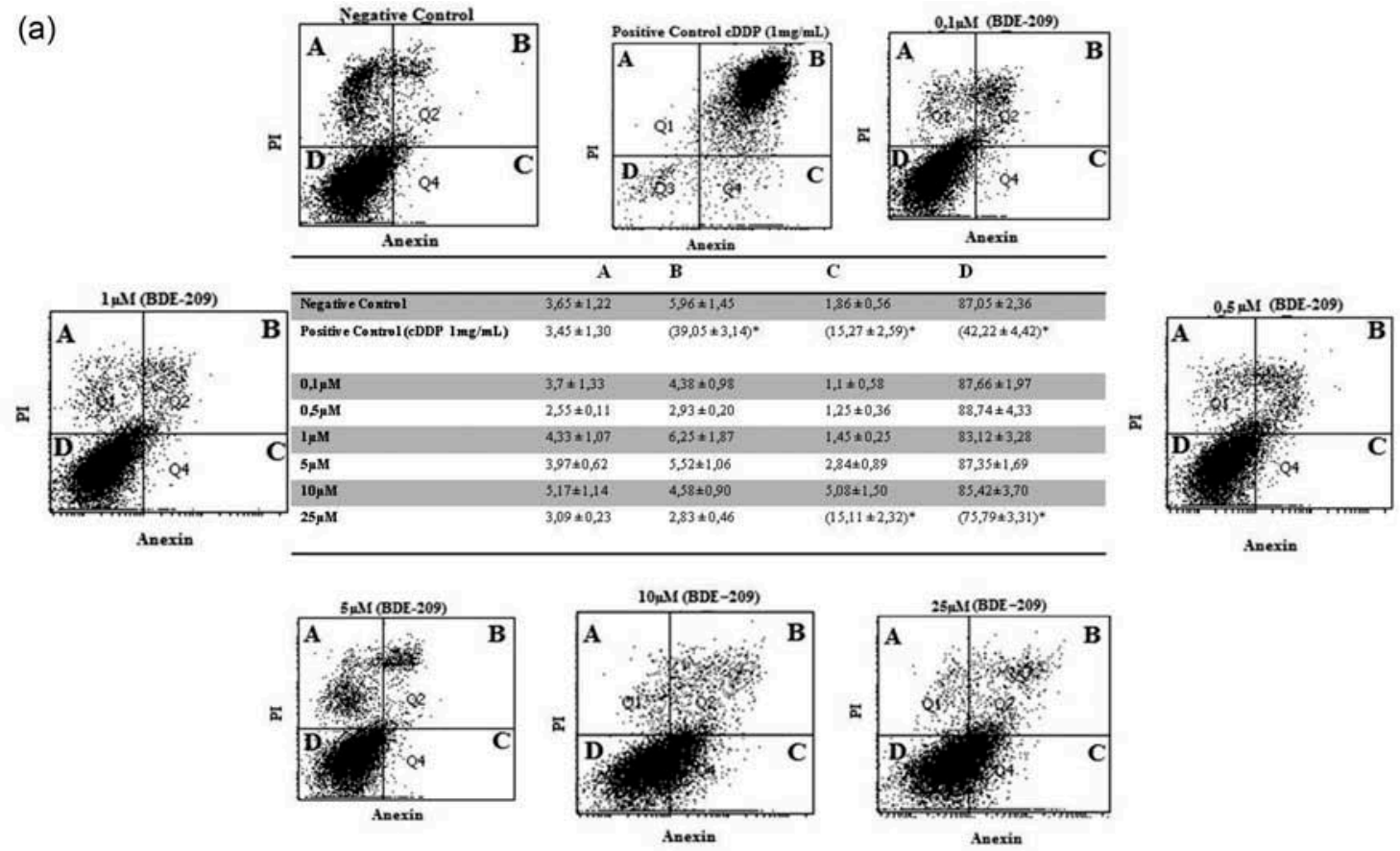

(b)
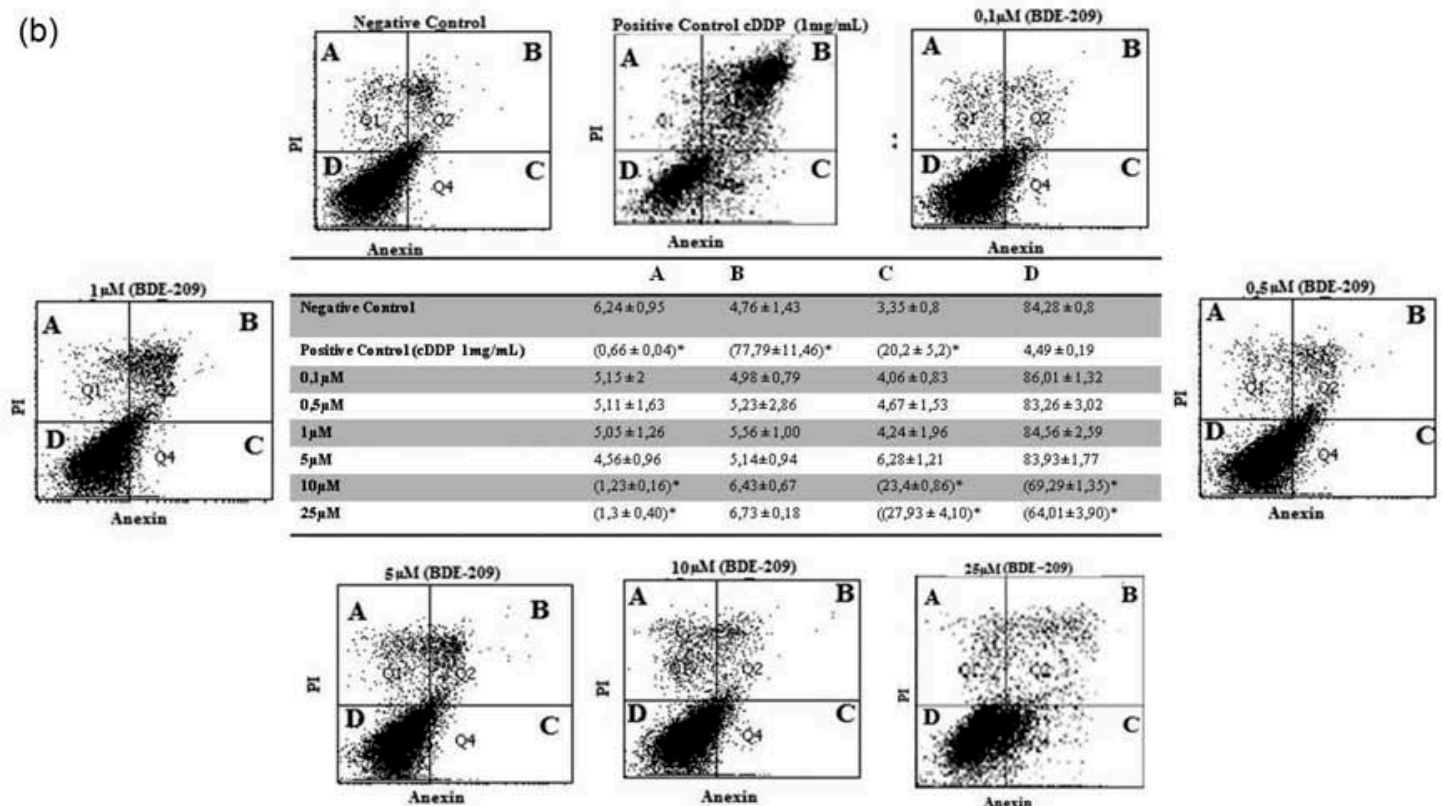

Figure 7. (A) BDE-209 (0.1-25 $\mu \mathrm{M})$ effects on phosphatidylserine (PS) exposure in HepG2 cells after $24 \mathrm{~h}$ cell incubation. PS exposure was assessed by the Annexin-V (Anex.)/Propidium lodide (PI) assay, as described in Materials and Methods. (B) BDE-209 (0.1-25 $\mu \mathrm{M}$ ) effects on PS exposure of HepG2 cells after $48 \mathrm{~h}$ incubation. PS exposure was assessed by the Anex./PI assay, as described in Materials and Methods. Images are representative of three experiments with different cell cultures, $\mathrm{A}\left(\mathrm{PI}^{+}\right.$and $\left.\mathrm{Anex}{ }^{-}\right), \mathrm{B}\left(\mathrm{Pl}^{+}\right.$and $\left.\mathrm{Anex}{ }^{+}\right), \mathrm{C}\left(\mathrm{PI}^{-}\right.$and Anex $\left.{ }^{+}\right)$, and $\mathrm{D}$ $\left(\mathrm{PI}^{-}\right.$and Anex $\left.{ }^{-}\right)$. Results are presented as means \pm SEM of a series of three experiments. * Significantly different $(p<0.05)$ from negative control (without BDE-209). The positive control was $1 \mathrm{mg} / \mathrm{ml}$ cisplatin solution (CDDP).

reaction with cyclophilin $\mathrm{D}$ and adenine nucleotide translocator (Yarana et al. 2012). In the present study, CsA was found to completely block BDE-209-induced mitochondrial swelling. However, RR, which is the non-competitive inhibitor of the $\mathrm{Ca}^{+}$uniporter in mitochondria and which blocks several mechanisms involved in intracellular $\mathrm{Ca}^{+}$regulation, did not elicit this effect (Dikalov et al. 2012). When the pore opens, ATP depletion occurs (Halestrap 2004; Leist et al. 1997). Hence, mitochondrial swelling initiated by BDE-209 opens the permeability 


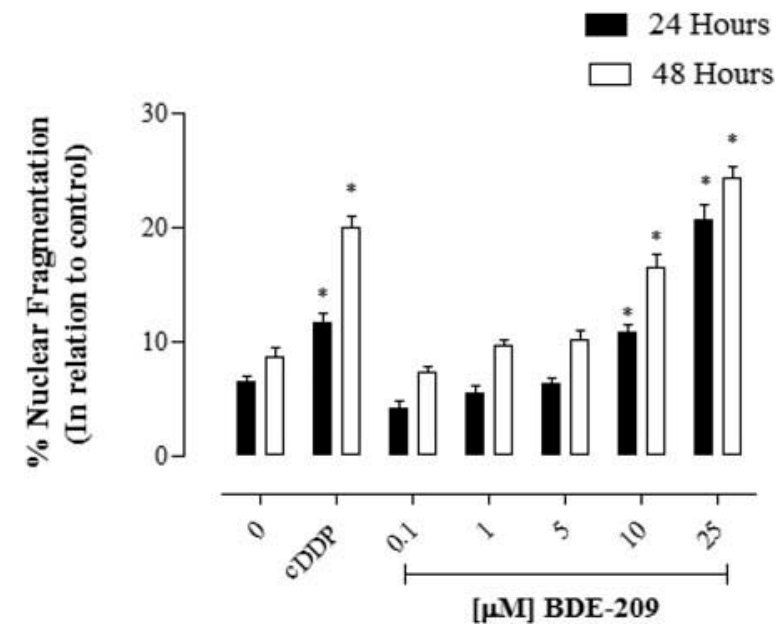

Figure 8. BDE-209 (0.1-25 $\mu \mathrm{M})$ effects after 24 or $48 \mathrm{~h}$ incubation of HepG2 cells. Nuclear fragmentation was assessed by fluorescence microscopy by using the fluorescent dye Hoechst 33342 as described in Materials and Methods. Data presented as means \pm SEM of a series of three experiments. *Significantly different ( $p<0.05$ ) from negative control (without BDE-209). The positive control was $1 \mathrm{mg} / \mathrm{ml}$ cisplatin solution (CDDP).

transition pore and produces ATP depletion, which culminates in cell death. Altered ATP levels are common in both apoptotic and necrotic processes. The only difference is that ATP depletion during apoptosis is not as marked as ATP depletion during necrosis (Leist et al. 1997; Malik and Czajka 2012). Different chemical substances are capable of lowering ATP content, and most of these reactions are related to interference with mitochondria oxidative phosphorylation processes, acting on the electron transport chain or on ATP synthase. It is also possible that these agents produce degradation of ATP molecules or even increase consumption of the ATP. Regardless of the reason that led to this ATP fall, the affected tissue suffers from consequences of energy inefficiency. In this study, it was found that ATP depletion mediated by BDE-209 exposure was not in concentration-dependent manner as previously noted for BDE-100 (Pereira et al. 2013).

A number of PBDE congeners, including BDE-209, were reported to induce mitochondrial dysfunction and consequent apoptotic cell death in human hepatoblastoma (Hu et al. 2007, 2009; Souza et al. 2013). Previously $\mathrm{Hu}$ and coworkers $(2007,2009)$ noted that higher BDE-209 concentration initiated mitochondrial dysfunction, but our findings showed that BDE-209 interacted with mitochondria at concentrations as low as $0.1 \mu \mathrm{M}$, and that the damage observed in isolated mitochondria consequently triggered cell death. This observation as well as ROS accumulation was previously reported due to PBDE-mediated toxicity in numerous cell lines (Costa and Giordano 2007; Frouin et al. 2010; Madia et al. 2004; Shao et al. 2008; Yan et al. 2010). In agreement with these findings, our data demonstrated that at even lower concentrations BDE-209 enhanced ROS generation, which subsequently led to oxidative stress. ROS generation is currently considered to underlie various diseases as well as the mechanism underlyin toxicity of many xenobiotics (Bernardi et al. 1999; Ghio et al. 2012; Kowaltowski and Vercesi 1999; Wallace 2000).
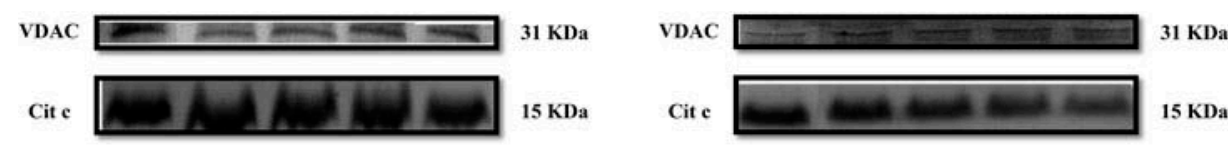

$\mathbf{A}$

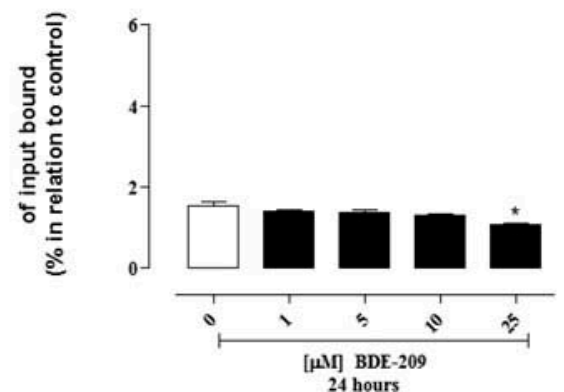

B

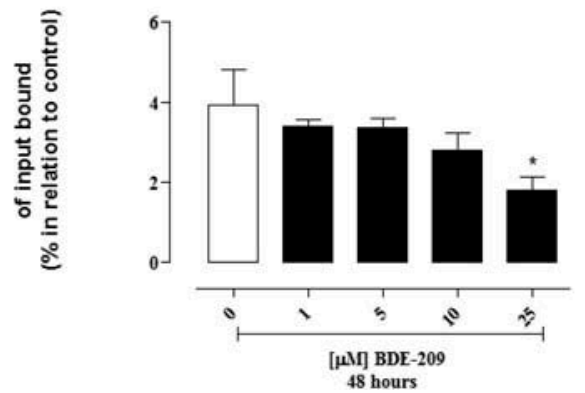

Figure 9. BDE-209 (0.5-25 $\mu \mathrm{M})$ effects after 24 or $48 \mathrm{~h}$ incubation of HepG2 cells. The cytochrome $c$ content was assessed by western blotting as described in Materials and Methods. Data presented as means \pm SEM of a series of three experiments. ${ }^{*}$ Significantly different $(p<0.05)$ from negative control (without BDE-209). 

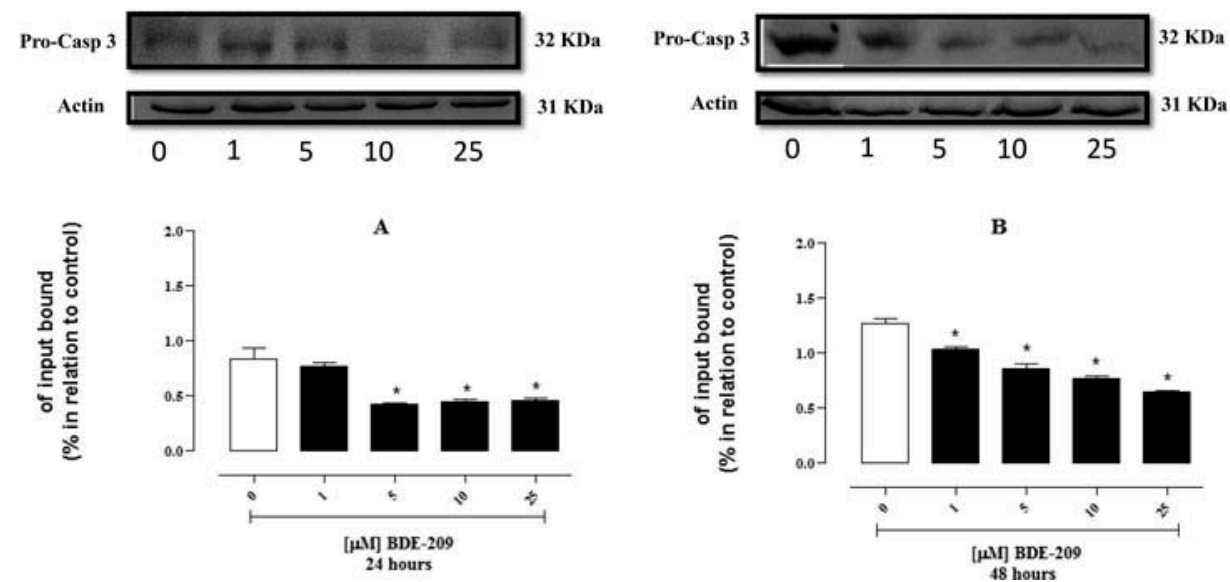

Figure 10. Influence of BDE $209(0.5-25 \mu \mathrm{M})$ after 24 or $48 \mathrm{~h}$ incubation of HepG2 cells. The pro-caspase 3 contents were assessed by western blotting as described in Materials and Methods. Data presented as means \pm SEM of a series of three experiments. *Significantly different $(p<0.05)$ from negative control (without BDE-209).
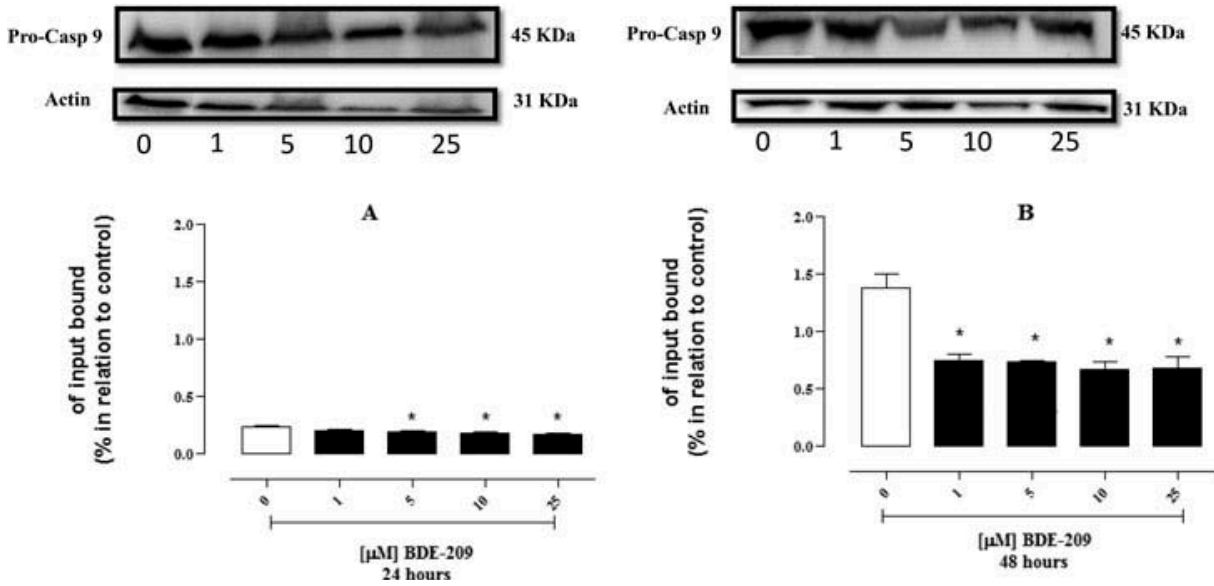

Figure 11. Influence of BDE $209(0.5-25 \mu \mathrm{M})$ after 24 or $48 \mathrm{~h}$ incubation of HepG2 cells. The pro-caspase 9 contents were assessed by western blotting as described in Materials and Methods. Data presented as means \pm SEM of a series of three experiments. *Significantly different $(p<0.05)$ from negative control (without BDE-209).

Since BDE-209 is known to induce oxidative stress, influence MPT, and reduce ATP levels in isolated rat mitochondria, it was postulated that BDE-209 affected mitochondrial functions in HepG2 cells. In fact, in the present investigation, mitochondrial transmembrane potential dissipation, nuclear fragmentation, and modified outer cell membrane PS exposure after incubation of HepG2 cells with BDE-209 was found. These findings are in agreement with those of Souza et al. (2013).

Activation of caspase-3, a final protease in the apoptotic cascade also confirms that BDE-209 exposure leads to apoptotic cell death (Brentnall et al. 2013; Green and Reed 1998; Nagata 1997; Ouyang et al. 2012; Porter and Jänicke 1999).
However, different mechanisms might trigger apoptotic cell death (Ouyang et al. 2012), and MPT-mediated by BDE-209 in isolated rat liver mitochondria may also have occurred in HepG2 cells as evident from decreased MMP, cyt $c$ release, and caspase 9 activation, all of which also occurred in the case of HepG2 incubation with this compound (Souza et al. 2013). Cyt $c$ release is also correlated with apoptotic cell death of other persistent organic pollutants, such as PCB (Abella et al. 2015; Selvakumar et al. 2011; Zhong et al. 2015). Although lower BDE-209 concentrations did not significantly alter cyt $c$ levels, activation of caspase 9 was noted. Similarly other investigators reported that ROS 


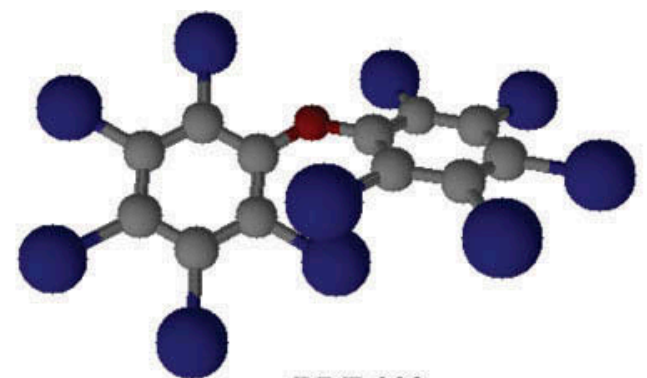

BDE 209

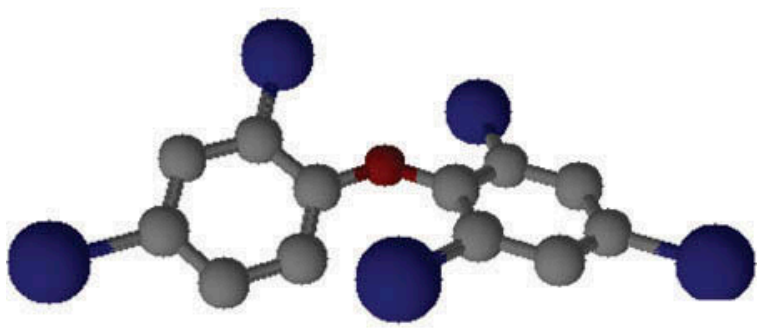

BDE 100

Figure 12. Tridimensional structures of BDE congeners: decaBDE (BDE 209) and tetra-BDE (BDE 100).

might mediate interaction with Apaf-1 and promote its auto-cleavage, consequently activating caspase 9 and caspase 3 (Kim and Park 2003; Zuo et al. 2009) as noted in our study. Therefore, oxidative stress initiated by BDE-209 in HepG2 cells might result in apoptosis at low BDE-209 concentrations.

Our results corroborate with data published for the BDE-209 congener but differ from results reported for penta- and tetra-BDE at other concentrations ( $\mathrm{Hu}$ et al. 2009; Souza et al. 2013). Taken together, our findings suggest that BDE-209 structure determines its action, indicating the basis for less toxicity to HepG2 cells compared to other PBDE congeners is chemical-structure related.

It is important to note that the concentrations that produced significant cytotoxic effects exceed the doses relevant for humans exposure and may not be environmentally relevant. However, data regarding the effects of PBDE on human cells presented herein are important to understand the toxicodynamics of this chemical.

In conclusion, BDE-209 triggers apoptotic cell death in HepG2 cells at high concentrations. Since BDE-209 interacts with mitochondria, this apoptotic process involves the mitochondrial pathway. Considering that BDE-209 accumulates in the environment and organisms, and that large quantities of BDE-209 are released daily into the environment, this congener remains a potential cause concern for the general public.

\section{Acknowledgments}

We thank Professor Carlos Curti PhD and the Biochemistry Laboratory at the Faculty of Pharmaceutical Sciences of Ribeirão Preto/Brazil for their technical support.

\section{Funding}

The authors are grateful to the Fundação de Amparo a Pesquisa do Estado de São Paulo - FAPESP (Proc. no. 2009/ 06912-6; 2010/02661-6 and 2012/13123-0), Brazil, for supporting this work.

\section{References}

Abella, V., A. Santoro, M. Scotece, J. Conde, V. López-López, V. Lazzaro, J. J. Gómez-Reino, R. Meli, and O. Gualillo. 2015. Non-dioxin-like polychlorinated biphenyls (PCB 101, PCB 153 and PCB 180) induce chondrocyte cell death through multiple pathways. Toxicol. Lett. 234:13-19. doi:10.1016/j. toxlet.2015.02.001.

Alves, C., F. L. Chagas, C. T. Souza, and M. B. P. Toralles. 2007. Environmental exposure to endocrine disruptors with estrogenic activity and the association with pubertal disorders in children. Cad. Saude Publica 23:1005-1014. doi:10.1590/S0102-311X2007000500003.

Bellinger, D. C. 2013. Prenatal exposures to environmental chemicals and children's neurodevelopment: An update. Saf. Health Work 4:1-11. doi:10.5491/SHAW.2013.4.1.1.

Bernardi, P., L. Scorrano, R. Colonna, V. Petronilli, and F. Di Lisa. 1999. Mitochondria and cell death. Mechanistic aspects and methodological issues. Eur. J. Biochem. 264:687-701. doi:10.1046/j.1432-1327.1999.00725.x.

Brentnall, M., L. Rodriguez-Menocal, R. L. De Guevara, E. Cepero, and L. H. Boise. 2013. Caspase-9, caspase-3 and caspase-7 have distinct roles during intrinsic apoptosis. BMC Cell Biol. 14:32. doi:10.1186/1471-2121-14-32.

Chen, J., C. Liufu, W. Sun, X. Sun, and D. Chen. 2010a. Assessment of the neurotoxic mechanisms of decabrominated diphenyl ether (PBDE-209) in primary cultured neonatal rat hippocampal neurons includes alterations in second messenger signaling and oxidative stress. Toxicol. Lett. 192:431-439. doi:10.1016/j.toxlet.2009.11.020.

Chernyak, B. V., D. S. Izyumov, K. G. Lyamzaev, A. A. Pashkovskaya, O. Y. Pletjushkina, Y. N. Antonenko, D. V. Sakharov, K. W. A. Wirtz, and V. P. Skulachev. 2006. Production of reactive oxygen species in mitochondria of HeLa cells under oxidative stress. Biochim. Biophys. Acta 1757:525-534. doi:10.1016/j.bbabio.2006.02.019. 
Costa, L. G., and G. Giordano. 2007. Developmental neurotoxicity of polybrominated diphenyl ether (PBDE) flame retardants. Neurotoxicology 28:1047-1067. doi:10.1016/j. neuro.2007.08.007.

Costa, L. G., and G. Giordano. 2011. Is decabromodiphenyl ether (BDE-209) a developmental neurotoxicant? Neurotoxicology 32:9-24. doi:10.1016/j.neuro.2010.12.010.

Cowens, K. R., S. Simpson, W. K. Thomas, and G. B. Carey. 2015. Polybrominated diphenyl ether (PBDE)-induced suppression of phosphoenolpyruvate carboxykinase (PEPCK) decreases hepatic glyceroneogenesis and disrupts hepatic lipid homeostasis. J. Toxicol. Environ. Health Part A 78:1437-1449. doi:10.1080/15287394.2015.1098580.

Darnerud, P. O. 2003. Toxic effects of brominated flame retardants in man and in wildlife. Environ. Int. 29:841853. doi:10.1016/S0160-4120(03)00107-7.

Denizot, F., and R. Lang. 1986. Rapid colorimetric assay for cell growth and survival: Modifications to the tetrazolium dye procedure giving improved sensitivity and reliability. J. Immunol. Meth. 89:271-277. doi:10.1016/0022-1759(86) 90368-6.

Dietz, R., F. F. Rigt, C. Sonne, R. J. Letcher, S. Backus, E. W. Born, M. Kirkegaard, and D. C. G. Muir. 2007. Age and seasonal variability of polybrominated diphenyl ethers in free-ranging East Greenland polar bears (Ursus maritimus). Environ. Pollut. 146:166-173. doi:10.1016/j. envpol.2006.05.040.

Dikalov, S. I., W. Li, A. K. Doughan, R. R. Blanco, and A. M. Zafari. 2012. Mitochondrial reactive oxygen species and calcium uptake regulate activation of phagocytic NADPH oxidase. Am J Physiol Regul Integr Comp Physiol 302:11341142. doi:10.1152/ajpregu.00842.2010.

Eskenazi, B., J. Chevrier, S. A. Rauch, K. Kogut, K. G. Harley, C. Johnson, C. Trujillo, A. Sjödin, and A. Bradman. 2013. In utero and childhood polybrominated diphenyl ether (PBDE) exposures and neurodevelopment in the CHAMACOS study. Environ. Health Persp. 121:257-262.

Frouin, H., M. Lebeuf, M. Hammill, S. Masson, and M. Fournier. 2010. Effects of individual polybrominated diphenyl ether (PBDE) congeners on harbour seal immune cells in vitro. Mar. Pollut. Bull. 60:291-298. doi:10.1016/j. marpolbul.2009.09.006.

Ghio, A. J., M. S. Carraway, and M. C. Madden. 2012. Composition of air pollution particles and oxidative stress in cells, tissues, and living systems. J. Toxicol. Environ. Health B 15:1-21. doi:10.1080/10937404.2012.632359.

Gill, S., Y. Hou, N. Li, O. Pulido, and W. Bowers. 2016. Developmental neurotoxicity of polybrominated diphenyl ethers mixture de71 in Sprague-Dawley rats. J. Toxicol. Environ. Health Part A 79:482-493. doi:10.1080/ 15287394.2016.1182001.

Goodman, J. E. 2009. Neurodevelopmental effects of decabromodiphenyl ether (BDE-209) and implications for the reference dose. Reg. Toxicol. Pharmacol. 54:91-104. doi:10.1016/j.yrtph.2009.02.006.

Green, D. R., and J. C. Reed. 1998. Mitochondria and apoptosis. Science 281:1309-1312. doi:10.1126/science.281.5381.1309.
Hale, R. C., M. J. La Guardia, E. Harvey, M. O. Gaylor, and T. M. Mainor. 2006. Brominated flame retardant concentrations and trends in abiotic media. Chemosphere 64:181-186. doi:10.1016/j.chemosphere.2005.12.006.

Halestrap, A. P. 2004. Mitochondrial permeability: Dual role for the ADP/ATP translocator? Nature 430:1. doi:10.1038/ nature 02816.

Hites, R. A. 2004. Polybrominated diphenyl ethers in the environment and in people: A meta-analysis of concentrations. Environ. Sci. Technol. 38:945-956. doi:10.1021/ es035082g.

$\mathrm{Hu}, \mathrm{X} ., \mathrm{D} . \mathrm{Hu}$, and Y. Xu. 2009. Effects of tetrabrominated diphenyl ether and hexabromocyclododecanes in single and complex exposure to hepatoma HepG2 cells. Environ. Toxicol. Pharmacol. 27:327-337. doi:10.1016/j. etap.2008.11.014.

Hu, X. Z., Y. Xu, D. C. Hu, Y. Hui, and F. X. Yang. 2007. Apoptosis induction on human hepatoma cells Hep G2 of decabrominated diphenyl ether (PBDE-209). Toxicol. Lett. 171:19-28. doi:10.1016/j.toxlet.2007.04.002.

Imberti, R., A. L. Nieminen, B. Herman, and J. J. Lemasters. 1993. Mitochondrial and glycolytic dysfunction in lethal injury to hepatocytes by t-butylhydroperoxide: Protection by fructose, cyclosporin A and trifluoperazine. J. Pharmacol. Exp. Ther. 265:392-400.

Jaeschke, H., G. J. Gores, A. I. Cederbaum, J. A. Hinson, D. Pessayre, and J. J. Lemasters. 2002. Mechanisms of hepatotoxicity. Toxicol. Sci. Orlando 65:166-176. doi:10.1093/ toxsci/65.2.166.

Jin, S., F. Yang, Y. Hui, Y. Xu, Y. Lu, and J. Liu. 2010. Cytotoxicity and apoptosis induction on RTG-2 cells of 2,2凹,4,4凶-tetrabromodiphenyl ether (BDE-47) and decabrominated diphenyl ether (BDE-209). Toxicol. in Vitro 24:1190-1196. doi:10.1016/j.tiv.2010.02.012.

Kim, J. Y., and J. H. Park. 2003. ROS-dependent caspase-9 activation in hypoxic cell death. FEBS Lett. 549:94-98. 95-96. doi:10.1016/S0014-5793(03)00795-6.

Kowaltowski, A. J., and A. E. Vercesi. 1999. Mitochondrial damage induced by conditions of oxidative stress. Free Radic. Biol. 26:463-471. doi:10.1016/S0891-5849(98) 00216-0.

Laemmli, U. K. 1970. Cleavage of structural proteins during the assembly of the head of bacteriophage T4. Nature 227:680-685. doi:10.1038/227680a0.

Lee, J., B. P. Yu, and J. P. Herlihy. 1999. Modulation of cardiac mitochondrial membrane fluidity by age and calorie intake. Free Radic. Biol. Med. 26:260-265. doi:10.1016/ S0891-5849(98)00195-6.

Lee, S., K. Kannan, and H. B. Moon. 2013. Assessment of exposure to polybrominated diphenyl ethers (PBDEs) via seafood consumption and dust ingestion in Korea. Sci. Total Environ. 443:24-30. doi:10.1016/j.scitotenv.2012.10.099.

Leist, M., B. Single, A. F. Castoldi, S. Kühnle, and P. Nicotera. 1997. Intracellular adenosine triphosphate (ATP) concentration: A switch in the decision between apoptosis and necrosis. J. Exp. Med. 185:1481-1486. doi:10.1084/ jem.185.8.1481. 
Madia, F., G. Giordano, V. Fattori, A. Vitalone, I. Branchi, F. Capone, and L. G. Costa. 2004. Differential in vitro neurotoxicity of the flame retardant PBDE-99 and of the PCB Aroclor 1254 in human astrocytoma cells. Toxicol. Lett. 154:11-21. doi:10.1016/j.toxlet.2004.06.013.

Malik, A. N., and A. Czajka. 2012. Is mitochondrial DNA content a potential biomarker of mitochondrial dysfunction? Mitochondrion 13:481-492. doi:10.1016/j. mito.2012.10.011.

McDonald, T. 2002. A perspective on the potential health risks of PBDEs. Chemosphere 46:745-755. doi:10.1016/ S0045-6535(01)00239-9.

Meironyte, D., K. Norén, and A. Bergman. 1999. Analysis of polybrominated diphenyl ethers in Swedish human milk. A time-related trend study, 1972-1997. J. Toxicol. Environ. Health Part A 58:329-341. doi:10.1080/009841099157197.

Mingatto, F. E., A. C. Dos Santos, T. Rodrigues, A. A. Pigoso, S. A. Uyemura, and C. Curti. 2000. Effects of nimesulide and its reduced metabolite on mitochondria. $\mathrm{Br}$. J. Pharmacol. 131:1154-1160. doi:10.1038/sj.bjp.0703667.

Moon, H.-B., M. Choi, J. Yu, R.-H. Jung, and H.-G. Choi. 2012. Contamination and potential sources of polybrominated diphenyl ethers (PBDEs) in water and sediment from the artificial Lake Shihwa, Korea. Chemosphere 88:837-843. doi:10.1016/j.chemosphere.2012.03.091.

Nagata, S. 1997. Apoptosis by death factor. Cell 88:355-365. doi:10.1016/S0092-8674(00)81874-7.

Nash, J. T., D. T. Szabo, and G. B. Carey. 2013. Polybrominated diphenyl ethers alter hepatic phosphoenolpyruvate carboxykinase enzyme kinetics in male Wistar rats: Implications for lipid and glucose metabolism. J. Toxicol. Environ. Health Part A 76:142-156. doi:10.1080/ 15287394.2012 .738457$.

Ouyang, L., Z. Shi, S. Zhao, F.-T. Wang, -T.-T. Zhou, B. Liu, and J.-K. Bao. 2012. Programmed cell death pathways in cancer: A review of apoptosis, autophagy and programmed necrosis. Cell Prolif. 45:487-498. doi:10.1111/cpr.2012.45. issue-6.

Pazin, M., L. C. Pereira, and D. J. Dorta. 2015. Toxicity of brominated flame retardants, BDE-47 and BDE-99 stems from impaired mitochondrial bioenergetics. Toxicol. Mech. Meth. 25:34-41. doi:10.3109/15376516.2014.974233.

Pedersen, P. L., J. W. Greenawalt, B. Reynafarje, J. Hulliher, G. L. Decker, J. W. Soper, and E. Bustamente. 1978. Preparation and characterization of mitochondria and submitochondrial particules of rats liver: Derived tissues. Meth. Cell. Biol. 20:411-481.

Pereira, L. C., A. O. De Souza, and D. J. Dorta. 2013. Polybrominated diphenyl ether congener (BDE-100) induces mitochondrial impairment. Basic Clin. Pharmacol. Toxicol. 112:418-424. doi:10.1111/bcpt.2013.112.issue-6.

Pereira, L. C., A. O. De Souza, M. F. Franco-Bernardes, M. Pazin, M. J. Tasso, P. H. Pereira, and D. J. Dorta. 2015. A perspective on the potential risks of emerging contaminants to human and environmental health. Environ. Sci. Pollut. Res. 22:13800-13823. doi:10.1007/s11356-0154896-6
Pereira, L. C., L. F. C. Miranda, A. O. De Souza, and D. J. Dorta. 2014. BDE-154 induces mitochondrial permeability transition and impairs mitochondrial bioenergetics. J. Toxicol. Environ. Health. A 77:24-36. doi:10.1080/ 15287394.2014.861337.

Porter, A. G., and R. U. Jänicke. 1999. Emerging roles of caspase-3 in apoptosis. Cell Death Differ. 6:99-104. doi:10.1038/sj.cdd.4400476.

Rice, D. C., E. A. Reeve, A. Herlihy, R. Thomas Zoeller, W. Douglas Thompson, and V. P. Markowski. 2007. Developmental delays and locomotor activity in the C57BL6/J mouse following neonatal exposure to the fullybrominated PBDE, decabromodiphenyl ether. Neurotoxicol. Teratol. 29:511-520. doi:10.1016/j.ntt.2007.03.061.

Riu, A., J.-P. Cravedi, L. Debrauwer, A. Garcia, C. Canlet, I. Jouanin, and D. Zalko. 2008. Disposition and metabolic profiling of [14C]-decabromodiphenyl ether in pregnant Wistar rats. Environ. Int. 34:318-329. doi:10.1016/j. envint.2007.03.007.

Sacks, V. P., and R. Lohmann. 2012. Freely dissolved PBDEs in water and porewater of an urban estuary. Environ. Pollut. 162:287-293. doi:10.1016/j.envpol.2011.11.028.

Selvakumar, K., L. Sheerin Banu, G. Krishnamoorthy, P. Venkataraman, P. Elumalai, and J. Arunakaran. 2011. Differential expression of androgen and estrogen receptors in PCB (Aroclor 1254)-exposed rat ventral prostate: Impact of alpha-tocopherol. Exp. Toxicol. Pathol. 63:105-112. doi:10.1016/j.etp.2009.10.003.

Shao, J., C. C. White, M. J. Dabrowski, T. J. Kavanagh, M. L. Eckert, and E. P. Gallagher. 2008. The role of mitochondrial and oxidative injury in BDE 47 toxicity to human fetal liver hematopoietic stem cells. Toxicol. Sci. 101:81-90. doi:10.1093/toxsci/kfm256.

Shen, K., C. Shen, J. Yu, C. Yu, L. Chen, D. Shi, and Y. Chen. 2011. PCB congeners induced mitochondrial dysfunction in Vero cells. J. Hazard. Mater. 185:24-28. doi:10.1016/j. jhazmat.2010.08.061.

Skehan, P., R. Storeng, D. Scudeiro, A. Monks, J. Mcmahon, D. Vistica, J. T. Warren, H. Bokesch, S. Keney, and M. R. Boyd. 1990. New colorimetric cytotoxicity assay for anticancer-drug screening. J. Nat. Cancer Inst. 82:1107-1112. doi:10.1093/jnci/82.13.1107.

Souza, A. O., L. C. Pereira, D. P. Oliveira, and D. J. Dorta. 2013. BDE-99 congener induces cell death by apoptosis of human hepatoblastoma cell line: HepG2. Toxicol. In Vitro 27:580-587. doi:10.1016/j.tiv.2012.09.022.

Stapleton, H. M., and N. G. Dodder. 2008. Photodegradation of decabromodiphenyl ether in house dust by natural sunlight. Environ. Toxicol. Chem. 27:306-312. doi:10.1897/07301R.1.

Stapleton, H. M., S. M. Kelly, R. Pei, R. J. Letcher, and C. Gunsch. 2009. Metabolism of polybrominated diphenyl ethers (PBDEs) by human hepatocytes. Environ. Health Persp. 117:197-202. doi:10.1289/ehp.11807.

Stasinska, A., A. Reid, A. Hinwood, G. Stevenson, A. Callan, J. Odland, and J. Heyworth. 2013. Chemosphere Concentrations of polybrominated diphenyl ethers (PBDEs) in residential dust 
samples from Western Australia. Chemosphere 91:187-193. doi:10.1016/j.chemosphere.2012.12.044.

Viberg, H. 2009. Neonatal ontogeny and neurotoxic effect of decabrominated diphenyl ether (PBDE 209) on levels of synaptophysin and tau. Int. J. Dev. Neurosci. 27:423-429. doi:10.1016/j.ijdevneu.2009.05.007.

Wallace, D. C. 2000. Mitochondrial defects in cardiomyopathy and neuromuscular disease. Am. Heart J. 139:S70-S85. doi:10.1067/mhj.2000.103934.

Yan, C., D. Huang, and Y. Zhang. 2011. The involvement of ROS overproduction and mitochondrial dysfunction in PBDE-47-induced apoptosis on Jurkat cells. Exp. Toxicol. Pathol. 63:413-417. doi:10.1016/j.etp.2010.02.018.

Yan, S., S. B. Subramanian, R. D. Tyagi, R. Y. Surampalli, and T. C. Zhang. 2010. Emerging contaminants of environmental concern: Source, transport, fate, and treatment. Pract. Period. Hazardous Toxic Radioact. Waste Manage. 14:2-20. doi:10.1061/(ASCE)HZ.1944-8376.0000015.

Yarana, C., J. Sripetchwandee, J. Sanit, S. Chattipakorn, and N. Chattipakorn. 2012. Calcium-induced cardiac mitochondrial dysfunction is predominantly mediated by cyclosporine A-dependent mitochondrial permeability transition pore. Arch. Med. Res. 43:333-338. doi:10.1016/ j.arcmed.2012.06.010.
Zhang, X., F. Yang, C. Xu, W. Liu, S. Wen, and Y. Xu. 2008a. Cytotoxicity evaluation of three pairs of hexabromocyclododecane (HBCD) enantiomers on Hep G2 cell. Toxicol. Vitro. 22:1520-1527. doi:10.1016/j. tiv.2008.05.006.

Zhang, Y., G. L. Guo, X. Han, C. Zhu, B. A. Kilfoy, Y. Zhu, P. Boyle, and T. Zheng. 2008b. Do polybrominated diphenyl ethers (PBDEs) increase the risk of thyroid cancer? Biosci. Hypotheses 1:195-199. doi:10.1016/j. bihy.2008.06.003.

Zhivotovsky, B., A. Samali, A. Gahm, and S. Orrenius. 1999. Caspases: Their intracellular localization and translocation during apoptosis. Cell Death Differ. 6:644-651. doi:10.1038/sj.cdd.4400536.

Zhong, Y., P. Guo, X. Wang, and J. An. 2015. Aroclor 1254 inhibits cell viability and induces apoptosis of human A549 lung cancer cells by modulating the intracellular $\mathrm{Ca}^{2+}$ level and ROS production through the mitochondrial pathway. J. Environ. Sci. Health Part A 50:806-813. doi:10.1080/ 10934529.2015.1019797.

Zuo, Y., B. Xiang, J. Yang, X. Sun, Y. Wang, H. Cang, and J. Yi. 2009. Oxidative modification of caspase- 9 facilitates its activation via disulfide-mediated interaction with Apaf-1. Cell Res. 19:449-457. doi:10.1038/cr.2009.19. 